\title{
Occupational Wellbeing Among Female Academics; the Influence of Family-Work Interface
}

\author{
O. S. Oludeyi ${ }^{1} *$ and O. E. Olajide ${ }^{2}$ \\ ${ }^{1}$ Department of Adult Education, Tai Solarin University of Education \\ ${ }^{2}$ Department of Adult Education, University of Ibadan
}

\begin{abstract}
There has been a plethora of research on work-life and work-family balance in Nigeria and across the globe, however there is still much to learn of the intersection between people's work and non-work life. This study examines the influence of work-family interface on occupational and general wellbeing of women in academia. A descriptive survey research design was adopted, with a researcherdesigned set of questionnaires of reliability co-efficient of 0.72 obtained through Cronbach alpha methods. A stratified random sampling technique was adopted in selecting 220 participants from two tertiary institutions in Ibadan, Nigeria out of which 181 were used for data analysis. Frequency Count, Standard Deviation, Pearson Product Moment Correlation and Rank Order were used for data analysis. Findings revealed that work-family interface significantly correlates with, and influences both occupational and general wellbeing of female lecturers. It was suggested that efforts should be geared towards ensuring that work-family balance policy options (such as job sharing, compressed working hours, selfrostering, telecommuting, flexi time, child-care assistance, and so forth) are made for women academics. Such policies should prioritise work flexibility for female academics.
\end{abstract}

Keywords: Female academics, general wellbeing, occupational wellbeing, tertiary institutions, work-family interface

\footnotetext{
*Correspondence should be addressed to Mr. O. S. Oludeyi, Department of Adult Education, College of Applied Education and Vocational Technology, Tai Solarin University of Education, Ijebu Ode, Ogun State, Nigeria (oludeyios@tasued.edu.ng)
} 


\section{Introduction}

In traditional African society, work activities were carried out simultaneously with domestic activities at home. It was purely an agricultural system where the family was a unit of production and productions were made purposely for family consumption (Fajana, 2006: 10; Googins, 1991). In those days, and to an extent presently in some rural areas, labour services were rendered on family agricultural farms and no wages were paid. Extra farm labour was seldom hired and in such cases, payments were made in kind, rather than cash, i.e., in terms of food, clothing and shelter (Fajana, 2006). There was division of labour as the father hunted for animals, the mother gathered fruits and vegetables, while the children handled house chores like sweeping, cooking and sometimes fetched water with the mother. The employer was the father and family head and was, at his discretion, all-in-all as he determined the reward system, recruitment, selection, promotion, and not necessarily based on merit or seniority. He provided food, housing and security for all the employees (mostly family members) and even determined when they would get married and to whom (Iwuji, cited in George, Owoyemi \& Onokala, 2012).

However, with the advent of the industrial revolution and the ensued technological advancement, people left agricultural and family business for paid employment in factories that were located outside the home. Clark (2000: 748), posits that the more industrialized the market economy became, the more workplaces were created outside the home and the more organisations, other than families, were in charge of productions. This physical and temporary separation between work and family lives poses several challenges to modern day employees. Since work and family are now in different domains or spheres which influence each other, certain changes in the nature of work and society have now emerged and increased the burden and responsibilities which are placed upon individuals both at work and at home. The work-family dichotomy also leads to a number of anomalies which, according to Brief and Nord, cited in Clark (2000) include; increase in divorce rates, leading to a high number of single parents; growing female participation in the labour force; more parttime work; increased labour mobility, which distances them from social supports of nuclear and extended families; changing employee expectations indicating greater interest in quality of life outside work; and growing social value placed on the fathers' involvement in the home [p.249]. 
Resultantly, one of the issues at the front burner in today's business world and among researchers in business and organisational behaviour is finding a balance between work and family life (Anafarta, 2011: 168; Fapohunda, 2014: 72) such that work-life conflicts can be managed if not eliminated totally. This is why there has been a plethora of research on work-life and work-family balance in Nigeria (see Adisa, Mordi \& Mordi, 2014; Akanji, 2013; Amazue, \& Ugwu, 2014; Fapohunda, 2014) and a substantial amount of studies of same concern have been done across the globe, (see Ahmed, Muddasar \& Perviaz, 2012; Anafarta, 2011; Arif, \& Farooqi, 2014; Shujat, Cheema \& Bhutto, 2011; among others). However, there is still much to understand about the intersection between people's work and non-work life. Specifically, a scanty number of studies have been targeted at investigating female employees whose domestic responsibilities seem weightier than of male counterparts. This study thus, builds on work-family border theory (Clark, 2000: 751) to examine how female lecturers address the changing nature of their work and family commitments throughout their life course and how such interface influences their wellbeing, both at work and in general.

\section{Statement of the Problem}

Apart from the enormous day-to-day tasks of teaching, formulating questions, marking scripts, attending to students as guardians, engaging in research, supervising undergraduate and postgraduate students, performing community service duties (such as heading units and being members of committees etc) within and outside the university or college communities by academics, the tripartite demand that academic jobs place on lecturers is enormous. An academic staff member must be a teacher, researcher and community service provider (Akinjobi, 2013: 21; Kuther, 2015). For the female academics, research reveals that most academics' time is taken mostly by research and writing that are usually done in evenings and weekends. This is time that women need to keep up their homes and raise their families (Kuther, 2015). Since it is a must that female academics do research to keep their jobs and earn tenure while completing essential domestic obligations, they juggle career needs, family responsibilities towards husbands and children, socio-cultural responsibilities to and relationship with relatives; society and personal recreation needs (Akinjobi, 2013: 21). To balance these multiple conflicting roles of being a professional, a mother, a house worker, among others, is a stressful but indispensable routine. When domestic work is coupled with a busy professional life, the workload can become burdensome, and it 
increases significantly as she procreates. Consequently, they suffer from strange rashes, neck and back problems, rheumatoid arthritis, breast infections, asthma, lupus among others (Kuther, 2015).

Unfortunately, stressors are interactive and cumulative: the more stressors one experiences, the greater the likelihood of stress-related health problems (Kuther, 2015). It may degenerate into hidden injuries resulting from exhaustion, overload, insomnia, anxiety, shame, aggression, hurt, guilt and feelings of being out-of-place, fraudulence and fear of exposure within the contemporary academy (Gill, 2009:1). It is against this backdrop that a study of this kind becomes imperative, such that the following research questions can be addressed:

1. Is there a relationship between work-family interface and general wellbeing among academics?

2. Does the interface of work and family significantly affect the occupational wellbeing of female academics?

3. In what areas of general wellbeing does work-family interface have the highest or lowest influence?

4. In what areas of occupational wellbeing does work-family interface have the highest or lowest influence?

5. Do female academics in different higher institutions of learning differ in their perceptions about work-family interface and occupational wellbeing?

\section{Literature Review}

Occupation refers to a group of everyday life goal-directed activities which are associated with any life domain but not necessarily work, such as leisure, education, or self-care (Anabym, Jarus, Backman, \& Zumb, 2010: 81). However, work activities take more (both physically and mentally) from individuals than other daily engagements which raises the question of workplace wellness more often than wellness in general aspects of life. Hence, the concept of occupational wellbeing has gained popularity over the past few years (CIPD, 2007:1) because it has been recognised as a key factor in determining an organisation's long-term effectiveness (ILO, 2009). Many scholars have attempted a conceptualisation of occupational wellbeing but the definitions, even though related, overlap significantly. According to ILO (2009) and Marie-Amélie, et al., (2013:1) occupational wellbeing relates to all aspects of working life, from the quality and safety of the physical environment, to how workers feel about their work, their working environment, the climate at work and work organization. Whereas wellbeing is more than an avoidance of becoming physically sick, it involves creating 
an environment to promote a state of contentment which allows (an) employees to flourish and achieve their full potential for the benefit of themselves and their organisation (CIPD, 2007: 4). Although this common and everyday view of occupations as work, employment, or one's chosen career rather than recognizing that occupations refer to everything that people do during the course of everyday lives has been criticised by recent scholars (Davis \& Polatajko, 2010; Singh, 2014:24). To conceptualise occupational wellbeing in such perspective will amount to reducing it to 'workplace' wellbeing. Occupational wellbeing refers to the wellbeing derived from participation and engagement in meaningful and valued occupations which may include but is not exclusively limited to paid work (CAOT, 2007; Singh, 2014: 24). This is why occupational wellbeing is subdivided into two categories (workplace and general wellbeing) in this paper.

\section{Dimensions of Wellbeing}

It appears that wellness has varieties of domains (CIPD, 2007), categories, levels or types (Grebner, Semmer, \& Elfering, 2005). Grebner, et al., did a longitudinal research on working conditions which shows three types of wellbeing: general wellbeing, job-related wellbeing and spill-over from work to non-work domains. This categorisation is in congruence with that of the Black Dog Institute except that the latter's has more detailed and specific types of wellbeing. Researchers at the Institute came up with results indicating where an individual sits on the following four areas of occupational wellbeing: a) work satisfaction, b) organisational respect for the employee, c) employer care, d) intrusion of work into private life. Another set of scholars also categorised aspects of human wellbeing using different indices in different contexts. Ryff and her colleagues studied a general context, and came up with 'sixdimensional context-free model' of well-being (Ryff, 1989; Ryff \& Keyes, 1995). These dimensions include: a) self-acceptance: a positive evaluation of oneself and one's past life; b) environmental mastery: the capacity to effectively manage one's life and the surrounding world; c) autonomy: a sense of self-determination and the ability to resist social pressures to think and act in certain ways; d) positive relations with others, expressed by, for instance, a genuine concern about the welfare of others; e) personal growth: the sense of continued growth and development as a person as well as openness to new experiences; and f) purpose in life: the belief that one's life is purposeful and meaningful and that one has something to live for. 
This is context-free while a study on job-specific wellbeing by Warr (1994) reveals four dimensions of job-specific wellbeing to include: affective wellbeing, aspiration, autonomy and competence. These four dimensions are considered by Warr as primary while a secondary fifth dimension; 'integrated functioning' was added. The fifth dimension encompasses the four primary dimensions of wellbeing and reflects the person as a whole (Warr, 1994). The CIPD, (2007: 8) also developed five domains of occupational wellbeing to include: a) Physical wellbeing (whether an individual is healthy or sick); b) emotional wellbeing (whether an individual is contented or distressed); c) wellbeing on personal development (whether an individual is flourishing or demotivated); d) wellbeing on values (whether an individual is committed or disengaged); and e) wellbeing on organisation or work (whether an individual is prospering or failing). With its general and work-specific nature, wellbeing is understood to be best mixed with other aspects of personal life among which family is most significant. Hence, the study of familywork interface and occupational wellbeing is desirable.

\section{Studies on Work-life Interface and General Wellbeing}

A growing body of empirical studies now focus on wellbeing and its connection with other variables within and outside organisations. In the past two to three decades, many studies on workplace have concentrated on its connection or benefits to individuals, organisations and societies in general. The studies of Betsey \& Justin, 2013; Böckerman, et al., 2012; Cotton \& Hart 2003; Dame, 2006; Davis \& Polatajko, 2010; Graham, 2003; Marie-Amélie, et al., 2013; Singh, 2014; Tehrani, et al., 2012; Willmott \& Haslam, 2007; Wood, 2010; among others, have all made efforts towards adding to our understanding of wellbeing. While the study of Dame (2006) examined the best way to manage workplace wellness to boost employee as well as business performance, studies of Böckerman, et al., (2013) investigated variables like high management involvement and their influence on employee wellbeing. Various other scholars show connections between wellbeing and performance (Cotton \& Hart 2003), productivities (Graham, 2003), job design (Wood, 2010), work-related stress, (Siti Aisyah, et al, 2012), income (Betsey, \& Justin, 2013), burnout, (Singh, 2014) among others. A wide array of revelations has been made from the outcomes of these studies. Yet, there are only a few studies on wellbeing in connection to the concept of work-family interface especially among academia. Does it mean that the interface of work and family is so insignificant to people's wellbeing, or has it been a widely known phenomenon, that it does not need further empirical probing? For the sake of empirical 
confirmation, it can be stated hypothetically that work-family interface may influence workers' wellbeing (research question 1):

Is there a relationship between work-family interface and general wellbeing among academics?

\section{Studies on Female Academics and Workplace Wellbeing}

In spite of the recent public enlightenment and campaign for gender mainstreaming in paid work, work roles are still seen to be men's primary domain while women are still primarily responsible for the home and children (Doucet, 2000; Noor, 2003: 298; Windebank, 2001). The situation is worse in the African continent where patriarchy is more intense. The perceptive distribution of work roles is not likely to be given prominence at the place of work where men and women who earn the same amount are expected to undertake the same weight of tasks. This makes work-family roles of women more complex than men's. Studies of Noor (2003), accounted for a number of family-related and work-related roles (variables) that seriously undermine women's general wellbeing. However, the study was not carried out in the African context and it was not particularly focused on female, academics. Other studies that have given attention to female academics occupational wellbeing are either conducted in contexts foreign to Africa (see Kinnunen, Feld, Geurts \& Pulkkinen, 2006; Schmidt \& Umans, 2014) or are not with special attention on work-family interface (see Cusack \& Numer, 2012; Daukantaité, 2006; Hellsten, Martin, McIntyre \& Kinzel, 2011; Mugweni, Mufanechiya \& Dhlomo, 2011; among others).

While the study of Kinnunen, et al., (2006), examined the negative and positive spill over between work and family as influenced by work-family interface among Finnish women, the study of Schmidt and Umans, (2014) investigated the experiences of well-being among female doctoral students in Sweden. Noor (2003) examined workrelated and family related variables as they influence the wellbeing of British women in Malaysia; a context where patriarchy is not strongly practised as it is in Nigeria. These studies would have provided us with adequate information of work-family interface and occupational wellbeing of female academics if conducted in cultural areas where women roles are perceived to be dominant at home. Unfortunately also, while the doctoral study of Daukantaite (2006), on middle-aged Swedish women's general Subjective Wellbeing focused on the importance of childhood factors, social circumstances, and personality, other studies on women wellbeing 
in university work tried to relate wellbeing to job-related stress, personality, and burnout among College of Education lecturers (Salami, 2009) social support (Salami, 2009; Cusack \& Numer, 2012), hopes and hiccups concerning promotion (Mugweni, et al., 2011), academic track tenure, (Hellsten, et al., 2011), among others. None of these empirical studies show connections between workfamily interface and workplace wellbeing. The study of AsieduAppiah, Aduse-Poku, and Acheampong (2014), which examined work-life balance of female lecturers in the African setting (Ghana) related it with career progression and not workplace wellbeing. Mugweni, et al., (2011) also investigated work-family conflict associating it with barriers to female lecturers' promotion and not on workplace wellbeing. However, in Nigeria, Ogbogu (2013) recently attempted a study of work-life balance among female academics in Nigeria but it was focused on job performance as the dependent variable. While the outcomes of these researches constantly demonstrated that work-family interface connects and affects certain aspects of female life, there is still much to understand about the intersection between female academics' job task/responsibilities and their wellbeing at work (workplace wellbeing) especially in the Nigerian context. This provokes the second research question:

Does the interface of work and family significantly affect workplace wellbeing of female academics?

\section{General/Context-free Wellbeing and Workplace Wellbeing}

In the literature, especially on the dimension of wellbeing, it appears undeniable that general wellbeing (as in the first research question) is not the same as workplace wellbeing (as in the second research). While the formal encompasses all aspects of wellbeing (such as, financial wellbeing, occupational wellbeing, workplace wellbeing, physical wellbeing, emotional wellbeing, family wellbeing, community wellbeing, among others), the latter simply refers to the wellbeing derived from participation and engagement in meaningful and valued occupations which may include but is not exclusively limited to paid work (CAOT, 2007; Singh, 2014: 24). Rather than reckoning with a particular model, the present study dwells on these multidimensional aspects of wellbeing to develop a framework (see Table 1 for the categories of wellbeing) considered suitable for the objects, subjects and context of this study. 
Table 1: Categories of wellbeing

\begin{tabular}{|c|c|}
\hline $\begin{array}{c}\text { Context-free or General } \\
\text { wellbeing }\end{array}$ & Job related wellbeing \\
\hline $\begin{array}{l}\text { Self-acceptance: a positive } \\
\text { evaluation of oneself and one's past } \\
\text { life; }\end{array}$ & $\begin{array}{l}\text { Physical wellbeing (whether an } \\
\text { individual is physical health at work } \\
\text { or often feel pain during and or after } \\
\text { work); }\end{array}$ \\
\hline $\begin{array}{l}\text { Environmental mastery: the } \\
\text { capacity to effectively manage one's } \\
\text { life and the surrounding world; }\end{array}$ & $\begin{array}{l}\text { Emotional wellbeing (whether an } \\
\text { individual is contented or distressed } \\
\text { at work); }\end{array}$ \\
\hline $\begin{array}{l}\text { Autonomy: a sense of self- } \\
\text { determination and the ability to } \\
\text { resist social pressures to think and } \\
\text { act in certain ways; }\end{array}$ & $\begin{array}{l}\text { Affective wellbeing (whether an } \\
\text { individual has personal affection or } \\
\text { passion for the work regardless of its } \\
\text { distastes) it also includes job } \\
\text { satisfaction }\end{array}$ \\
\hline $\begin{array}{l}\text { Positive relations with others, } \\
\text { expressed by, for instance, a } \\
\text { genuine concern about the welfare } \\
\text { of others; }\end{array}$ & $\begin{array}{l}\text { Wellbeing in autonomy and } \\
\text { competence (whether an individual } \\
\text { experience improvement in technical } \\
\text { knowhow and professional } \\
\text { understanding); }\end{array}$ \\
\hline $\begin{array}{l}\text { Personal growth: the sense of } \\
\text { continued growth and development } \\
\text { as a person as well as openness to } \\
\text { new experiences; }\end{array}$ & $\begin{array}{l}\text { Wellbeing in organisation or work } \\
\text { (whether an individual earns } \\
\text { organisational respect or gets } \\
\text { adequate employer care at work). }\end{array}$ \\
\hline $\begin{array}{l}\text { Purpose in life: the belief that one's } \\
\text { life is purposeful and meaningful } \\
\text { and that one has something to live } \\
\text { for. }\end{array}$ & $\begin{array}{l}\text { Aspirational wellbeing/wellbeing in } \\
\text { personal and occupational } \\
\text { development (whether an individual } \\
\text { is flourishing or demotivated on the } \\
\text { job); }\end{array}$ \\
\hline $\begin{array}{l}\text { Family: the distance or closeness to } \\
\text { friends and relatives }\end{array}$ & $\begin{array}{l}\text { Collegial wellbeing (whether an } \\
\text { individual is in good disposition and } \\
\text { pace with other colleagues on the job) }\end{array}$ \\
\hline
\end{tabular}

What may be interesting in the context of the present study is to ask the fundamental question of how work-family interface positively or negatively influence each domain or dimension of occupational and general wellbeing, hence the research question three and four:

On what areas of general wellbeing does work-family interface have highest or lowest influence?

On what areas of workplace wellbeing does work-family interface have highest or lowest influence? 


\section{Method}

Research design and procedure: This study adopts a descriptive survey research design; a set of questionnaires was used as instruments to collect data from the female academic staff about the influence of work-family interface on occupational wellbeing among them. To obtain data for this study, the researchers designed a set of questionnaires with a 7 point rating scale of work-family interface and occupational wellbeing. The reliability test of the instrument yielded reliability co-efficient of 0.72 obtained through Cronbach alpha methods. With the aid of two research assistants who were postgraduate students, a sample size of 220 female academics selected by stratified random sampling technique from two tertiary institutions. They are 117 from the University of Ibadan and 1wq from the Polytechnics Ibadan, Oyo State, Nigeria. In all, 201 questionnaires were retrieved giving a return rate of $91.4 \%$ but 181 were found useful for data analysis. The responses were scored and used to prepare a spread sheet on Microsoft Excel for computer analysis.

Data Analysis: The statistical techniques that were used for analysis of the data include the use of Frequency Count, Standard Deviation, Pearson Product Moment Correlation and Rank Order. The dependent variable was occupational wellbeing of female academics while the independent variable was the interface of work to family life of these women.

Participants: The mean age score of the participants was 36.70 years with a standard deviation of 4.50 ranging from 25 to 55 years. While $59 \%$ are married, $31.5 \%$ never married and $9.5 \%$ once married. The average number of years in service of participants was 10.6 years $($ S.D. $=5.60)$ ranging from 1 to 20 years. The highest educational qualifications of the participants varied: $\mathrm{PhD}(32.7 \%)$, M.Ed./M.A./M.Sc. (39.7\%), B.Sc./B.A./B.Ed. (17.8\%), Other qualifications $(9.8 \%)$. The current designation of the participants include 29 Assistant lecturers (16\%), 59 Lecturers I-II (32.6\%), 39 Senior Lecturers (21.5\%), 28 Associate Professors (15.5\%), and 26 Professors (14.4\%)

\section{Results}

Findings are presented in tabulated form according to research questions. 
Research question one: is there a relationship between work-family interface and general wellbeing among academics?

Table 2. Correlation between work-family interface and general wellbeing

\begin{tabular}{|l|l|l|l|l|l|}
\hline Variables & Mean & $\begin{array}{l}\text { Std. } \\
\text { Deviation }\end{array}$ & N & R & Sig \\
\hline $\begin{array}{l}\text { Work-family } \\
\text { interface }\end{array}$ & 16.58 & 4.218 & 181 & 0.777 & $0.000($ sig) \\
$\begin{array}{l}\text { General } \\
\text { wellbeing }\end{array}$ & 16.52 & 6.048 & 181 & \\
\hline
\end{tabular}

$$
(\mathrm{p}<0.01)
$$

Research question two: does the interface of work and family significantly affect workplace wellbeing of female academics?

Table 3. Correlation between work-family interface and workplace wellbeing of female academics

\begin{tabular}{|l|l|l|l|l|l|}
\hline Variables & Mean & $\begin{array}{l}\text { Std. } \\
\text { Deviation }\end{array}$ & N & R & Sig \\
\hline $\begin{array}{l}\text { Work-family } \\
\text { interface }\end{array}$ & 16.78 & 4.434 & 181 & & \\
$\begin{array}{l}\text { Workplace } \\
\text { wellbeing }\end{array}$ & 16.64 & 6.182 & 181 & 0.707 & $0.000($ sig) \\
\hline
\end{tabular}

$$
(\mathrm{p}<0.01)
$$

Research question three: on what areas of general wellbeing does work-family interface have highest or lowest influence?

Table 4. Ranking of areas of general wellbeing according to intensity of influence by work-family interface

\begin{tabular}{|l|l|l|l|l|l|l|l|}
\hline $\begin{array}{l}\text { Areas of } \\
\text { general } \\
\text { wellbeing }\end{array}$ & $\mathbf{N}$ & $\mathbf{M i n}$ & $\mathbf{M a x}$ & $\mathbf{M e a n}$ & $\begin{array}{c}\text { St. } \\
\text { Dev. }\end{array}$ & Rank & $\begin{array}{l}\text { Remarks } \\
\text { (Level of } \\
\text { influence) }\end{array}$ \\
\hline $\begin{array}{l}\text { Self- } \\
\text { acceptance }\end{array}$ & 181 & 1 & 7 & 3.30 & 1.672 & $7^{\text {th }}$ & Average \\
\hline $\begin{array}{l}\text { Environmental } \\
\text { mastery }\end{array}$ & 181 & 1 & 7 & 3.67 & 1.867 & 6 th & Average \\
\hline Autonomy & 181 & 1 & 7 & 3.32 & 1.672 & 5 th & Average \\
\hline $\begin{array}{l}\text { Positive } \\
\text { relations with }\end{array}$ & 181 & 1 & 7 & 3.78 & 1.971 & $4^{\text {th }}$ & Average \\
\hline
\end{tabular}




\begin{tabular}{|l|l|l|l|l|l|l|l|}
\hline others & & & & & & & \\
\hline $\begin{array}{l}\text { Personal } \\
\text { growth }\end{array}$ & 181 & 1 & 7 & 4.11 & 1.686 & $2^{\text {nd }}$ & Highest \\
\hline Purpose in life & 181 & 1 & 7 & 4.06 & 9.106 & $3^{\text {rd }}$ & High \\
\hline Family life & 181 & 1 & 7 & 4.21 & 2.186 & $1^{\text {st }}$ & Highest \\
\hline $\begin{array}{l}\text { Overall general } \\
\text { wellbeing }\end{array}$ & 181 & 8 & 45 & 26.87 & 9.106 & & Average \\
\hline
\end{tabular}

Research question four: on what areas of workplace wellbeing does work-family interface have highest or lowest influence among female academics?

Table 5. Ranking of areas of workplace wellbeing according to intensity of influence by work-family interface

\begin{tabular}{|l|l|l|l|l|l|l|l|}
\hline $\begin{array}{l}\text { Areas of occupational } \\
\text { wellbeing }\end{array}$ & $\mathbf{N}$ & Min & Max & Mean & $\begin{array}{l}\text { St. } \\
\text { Dev }\end{array}$ & $\begin{array}{l}\text { Ran } \\
\text { Ran }\end{array}$ & $\begin{array}{l}\text { Level of } \\
\text { influence }\end{array}$ \\
\hline Physical wellbeing & 181 & 1 & 7 & 3.37 & $\begin{array}{l}1.88 \\
6\end{array}$ & $6^{\text {th }}$ & Low \\
\hline Emotional wellbeing & 181 & 1 & 7 & 3.81 & $\begin{array}{l}136 \\
45\end{array}$ & 3 rd & Average \\
\hline Affective wellbeing & 181 & 1 & 7 & 3.33 & $\begin{array}{l}1.53 \\
5\end{array}$ & $7^{\text {th }}$ & Low \\
\hline $\begin{array}{l}\text { Wellbeing on } \\
\text { autonomy/ competence }\end{array}$ & 181 & 1 & 7 & 3.76 & $\begin{array}{l}1.71 \\
1\end{array}$ & 4 th & Average \\
\hline $\begin{array}{l}\text { Wellbeing on organisation } \\
\text { or work }\end{array}$ & 181 & 1 & 7 & 3.89 & $\begin{array}{l}1.76 \\
6\end{array}$ & $2^{\text {nd }}$ & Average \\
\hline $\begin{array}{l}\text { Aspirational wellbeing } \\
\text { Eollegial wellbeing }\end{array}$ & 181 & 1 & 7 & 4.17 & $\begin{array}{l}1.93 \\
9\end{array}$ & 1 st & Highest \\
\hline $\begin{array}{l}\text { Coverall workplace } \\
\text { wellbeing }\end{array}$ & 181 & 1 & 7 & 3.71 & $\begin{array}{l}2.01 \\
9\end{array}$ & $5^{\text {th }}$ & Average \\
\hline
\end{tabular}

\section{Discussion of Findings}

The study investigated the influence of work-family interface on occupational and general wellbeing of female lecturers in selected tertiary institutions in Ibadan south-western Nigeria. The analysis revealed that work-family interface significantly correlates with both occupational and general wellbeing of female lecturers. On general wellbeing, (first research question), the mean score of work-family 
interface was 16.58 with standard deviation of 4.218 while general wellbeing based on the interception had a mean score of 16.52 and standard deviation of 6.048. Correlation is 0.777 which is significant at 0.01. This means that work-family interface has a significant positive correlation with wellbeing in general. This finding corroborates earlier finding of Noor (2003) which accounted for a number of family-related and work-related roles (variables) that seriously undermine women's general wellbeing. On workplace wellbeing (second research question), the mean score for the interface of work and family is 16.78 while workplace wellbeing based on this interface is 16.64 . The correlation is 0.707 which is significant at 0.01 level (see Table three). It shows that the interface of work and family significantly affect workplace wellbeing of female academics. The more the task and responsibility of work intersects with family life, the more its effects intensify on their wellbeing at work. These findings build up to the existing body of knowledge advanced by previous other previous studies (such as Kinnunen, et al., 2006; Schmidt \& Umans, 2014) which investigated female academics' occupational wellbeing in contexts that are foreign to Africa. Earlier studies on occupational wellbeing among women have also examined its association with other variables such as job related stress, personality, and burnout (Salami, 2009) social support (Salami, 2009; Cusack \& Numer, 2012), hopes and hiccups concerning promotion (Mugweni, et al., 2011), and academic track tenure, (Hellsten, et al., 2011). The current finding suggests a new determinant factor (work-family interface) in occupational wellbeing.

In Table four, the third research question was addressed. The area of general wellbeing where work-family interface has highest influence is family life which has a mean score of 4.21 amounting to $60 \%$. The interpretation is that the distance and/or closeness to one's family and the extent to which one is responsible at home is the most affected by the interface of job to family life. This finding confirms the postulations of Brief and Nord, cited in Clark (2000) that workfamily dichotomy affects family life such that it leads to increased divorce rates, leading to a high number of single parents; increased labour mobility, which distances them from social supports of nuclear and extended families; and growing social value placed on fathers' involvement in the home [p. 249]. After family life, an area of general wellbeing where work-family interface has the second highest influence is on their personal growth with a mean score of 4.11 which amount to $58.7 \%$. Personal growth being the sense of continued growth and development as a person as well as openness to new experiences in life, has some consistence with recent findings of Asiedu-Appiah, et al. (2014: 426) which suggest that family-work 
conflicts have a negative effect on the career progression of female lecturers. Following this finding, it appears that whatever affects career progression or personal growth affects overall purpose in life. This is probably why the third area of general wellbeing where workfamily interface has the highest influence is their purpose in life. Purpose in life is defined as the belief that life is purposeful and meaningful and that female lecturers have something to live for. In other areas of general wellbeing, work-family interface has an average level of influence.

The last research question was addressed in Table five; the area of workplace wellbeing where work-family interface has highest influence is on aspirational wellbeing with a mean score of 4.17 $(59 \%)$. Aspirational wellbeing means wellbeing in personal and occupational development: whether an individual is flourishing or demotivated on the job. This finding is very crucial and critical and consistent with our findings on personalgrowth (under general wellbeing) with a mean score of 4.11 which amount to $58.7 \%$, an area where work-family interface has the second highest influence (see Table 4). This finding is meaningful because previous studies (see Mugweni, et al., 2011; Akinjobi, 2013; Asiedu-Appiah, et al., 2014) have demonstrated that work-life conflict has negative effects on the career progression of female lecturers. A majority of the respondents in the study of Asiedu-Appiah and his colleagues agreed that combining family and work-life affect female lecturers' ability to pursue further studies and publication. Their aspiration and ability to flourish at work is badly affected because academic qualification and research productivity are a major factor in career progression. In the same perspective with current findings on aspirational wellbeing, the study of Akinjobi, (2013: 21) revealed the challenges facing female academics such as juggling career needs with family responsibilities towards husbands and children, sociocultural responsibilities to and relationship with relatives; society and personal recreation needs, which seriously undermine their research productivities and ability to progress. The present findings also corroborate the findings of Mugweni, et al., (2011) which suggested that balancing work responsibility with the domestic role of female lecturers is one of the barriers and hiccups for rising to top leadership positions in universities. Asiedu-Appiah, et al., (2014: 426) also found $72.1 \%$ evidence that childbearing and child care negatively conflict with the job progression of female lecturers.

Except aspirational wellbeing, work-family interface has average effect on other areas of workplace wellbeing which include: wellbeing on organisation or work, whether an individual earns organisational 
respect or gets adequate employer care at work (55\%); emotional wellbeing, whether an individual is contented or distressed at work (54\%); wellbeing in autonomy and competence, whether an individual experiences improvement in technical knowhow and professional understanding $(53.5 \%)$. The area of workplace wellbeing where work-family interface has the lowest level of influence is affective wellbeing with a mean score of $3.33 \%$. The possible explanation of the low level of work-family influence on affective wellbeing is because, where it is affective, an individual is passionately committed to the work based on personal affection or drive which may neutralize the adverse effect of work-family interface.

\section{Conclusion and Recommendations}

Female academics' aspiration and ability to flourish at work is badly affected as work-family interface undermines their ability to pursue further studies and publications. They are grievously disadvantaged because the interface of work and family is found to affect their relationships with friends and members of their immediate families, while distancing them from their domestic responsibility and social supports from friends, relatives and possibly extended family members.

Based on these findings, it is recommended that government, university administrators and management alike, men whose wives are academics should bear in mind that the interception of work to family life has grievous effect on female lecturers' wellbeing both at work and in their general life. As such efforts should be geared towards ensuring that a work-family balance policy is crafted for women academics, especially those married who are in the process of procreating. Such policies should place top priority on 'work flexibility' and ensure adequate quality of working life for female academics. A number of work-life balance options may be incorporated into such policies. Such options include job sharing, compressed working hours, self-rostering, telecommuting, flexi time, child-care assistance, among others (see Fapohunda, 2014: 75).

The area of general wellbeing where work-family interface has highest influence is family life, as revealed in this study. There is, therefore, an urgent need for public campaign and enlightenment about gender mainstreaming in the perception and distribution of family responsibility. It is also important that, in the family institutions, women's homework, which includes but is not limited to child rearing and caring, cooking, housekeeping and other 
domestic responsibilities of women should be evenly divided between men and women, especially if they are both in paid employment. The perception that paid work is mostly men's primary domain, while women are perceived to be primarily responsible for the home and children should be corrected with immediate effect.

Whatever affects career progression or personal growth affects overall purpose in life, and the intersection between work and family life of female lecturers seriously undermines their career progression. These adverse effects can be mediated through various empowerment programmes or units targeted towards women in academia. These empowerment programmes or units, established in each campus, should consider first priority to expand job and career prospects for women academics for professional growth in teaching and research as well as personal development (aggrandisements.)

It is also pertinent to say that this study focused only on two tertiary institutions in Ibadan south western, Nigeria. Future studies may expand its scope to cover more state and federal institutions across south western region. It will also be useful to investigate and quantify the perception of female lecturers in universities as compared to those in polytechnics and colleges of educations in Nigeria. Future studies may also explore, compare and contrast the work-family balance policies that are most effective in reducing work-life conflict among women academics. Such studies may distinguish policies that are most effective in universities from those that are effective in polytechnics or colleges of education.

\section{References}

Adisa, T. A., Mordi, C. and Mordi, T. (2014). The challenges and realities of work-family balance among Nigerian female doctors and nurses. Economics Insights- Trends and Challenges, 3(5): 23-37. Accessed on 2 March 2015 at http://www.upg-bulletinse.ro/archive/2014-3/3.Adisa_Mordi_Mordi.pdf

Ahmed, M., Muddasar, M. and Perviaz, S. (2012). The impact of work-family conflict and pay on employee job satisfaction with the moderating effect of perceived supervisor support in Pakistan banking sector. Global Journal of Management and Business Research, 12(6): 37-44. Accessed on 2 March 2015 at https://globaljournals.org/GJMBR_Volume12/5-The-Impactof-Work-Family-Conflict.pdf 
Akanji, O. B. (2013), An exploratory study of work-life balance in Nigeria: employees' perspectives of coping with the role conflicts. International Journal of Research Studies in Management, 2 (2): 89-100. Accessed on 2 March 2015 at http://www.consortiacademia.org/index.php/ijrsm/article/vie w/415. http://dx.doi.org/10.5861/ijrsm.2013.415

Akinjobi, A. (2013) Balancing acts for African women development: challenges of women academics in Africa, the case of Nigeria. International Journal of Language, Literature and Gender Studies, 2 (2): 20-45. Accessed on 3 March 2015 at http://afrrevjo.net/journals/laligens/Vol_2_no_2_art_3_Akinjo bi.pdf

Amazue, L. O. and Ugwu, F. O. (2014) Ethnicity and self-esteem as predictors of work-family conflict among Nigerian workers. European Journal of Business and Management, 6 (26): 114-121

Anabym, D., Jarus, T., Backman, L. C. and Zumb, D. B. (2010), The role of occupational characteristics and occupational imbalance in explaining well-being. Applied Research Quality Life 5(1):81104 DOI 10.1007/s11482-010-9094-6

http://dx.doi.org/10.1007/s1 1482-010-9094-6

Anafarta, N. (2011). the relationship between work-family conflict and job satisfaction: a Structural Equation Modeling (SEM) approach International Journal of Business and Management 6 (4) retrieved on 16 March 2015 from http://www.ccsenet.org/journal/index.php/ijbm/article/view/ 10084. http://dx.doi.org/10.5539/ijbm.v6n4p168

Arif, B. and Farooqi, Y. A. (2014). Impact of work life balance on job satisfaction and organizational commitment among university teachers: a case study of University of Gujrat, Pakistan International Journal of Multidisciplinary Sciences and Engineering, 5 (9): 24-29. Accessed on 2-3-2015 at http://www.ijmse.org/Volume5/Issue9/paper5.pdf

Asiedu-Appiah, F., Aduse-Poku O. and Acheampong, A. F. (2014). Work-life balance practices and female lecturers' career progression in Ghana, Asian Journal of Management Research 4 (3), 419-439: Retrieved on 15 March 2015 from http://www.ipublishing.co.in/ajmrvol1 no1/volfour/EIJMRS40 34.pdf 
Betsey, S. and Justin, W. (2013) Subjective well-being and income: is there any evidence of satiation? American Economic Review: Papers and Proceeding. Available at http://www.brookings.edu/ /media/research/files/papers / 20 13/04/subjective\%20well\%20being\%20income/subjective\%20 well\%20being\%20income.pdf (accessed 12 November, 2014)

Böckerman, P., Bryson, A. and lmakunnas, P. (2012). Does High Involvement Management Improve Worker Wellbeing? CEP Discussion Paper No. 1095 Available at http://cep.lse.ac.uk/pubs/download/dp1095.pdf (accessed 12 November, 2014)

Canadian Association of Occupational Therapists. (2007). Enabling occupation II: Advancing occupational therapy vision for health, well-being and justice through occupation. Townsend, E., \&Polatajko, H. (Eds.) Ottawa, ON: CAOT Publications

Chattered Institute of Personnel Development (2007). What is happening with wellbeing at work? Accessed on 10-03-2015 at http:/ / www.cipd.co.uk/NR/rdonlyres/DCCE94D7-781A-485AA702-6DAAB5EA7B27/0/whthapwbwrk.pdf

Clark, C. S. (2000). Work/family border theory: a new theory of work/family balance. Human Relations, 53 (6) 747-770 retrieved on $16 \quad 2015$ fromhttps://www.academia.edu/3259995/Work_Family_Borde r_Theory_A_New_Theory_of_Work_Family_Balance also available at http://hum.sagepub.com/content/53/6/747 http://dx.doi.org/10.1177/0018726700536001

Cotton, P. and Hart, P. M. (2003). Occupational wellbeing and performance: a review of organisational health research. AustralianPsychologist, Vol. 32 (2) 118-127. Available at http:/ / www.rtwknowledge.org/browse.php?article_id=193\&vie w_type $=$ health $($ accessed 12 November, 2014) http://dx.doi.org/10.1080/00050060310001707117

Cusack, E. E. and Numer, M. (2012). A Phenomenological Inquiry of Social Support in Relation to Health and Wellbeing among Rural Queer Female Youth International Journal of Interdisciplinary Social Sciences, 6 (4) 35-48: Abstract available at http://iji.cgpublisher.com/product/pub.88/prod.1454 
Dame, C. B. (2006). Wellbeing at work: how to manage workplace wellness to boost your staff and business performance. Director Publications Ltd, 116 Pall Mall London SW1Y 5ED available at http:/ / www.director.co.uk/content/pdfs/wellbeing_guide.pdf (accessed 12 November, 2014)

Daukantaitè, D. (2006). Subjective well-being in Swedish women. A Doctoral dissertation, Department of Psychology, Stockholm University, Sweden. Retrieved on 15 March 2015 from http://www.divaportal.org/smash/get/diva2:189775/FULLTE XT01.pdf

Davis, J. A. \& Polatajko, H. J. (2010). Don't forget the repertoire: the meta occupational issue. Occupational Therapy Now, 12(3), 2022 .

Doucet, A. (2000). There's a huge gulf between me as a male carer and woman. Gender, domestic responsibility, and the community as an institutional arena.Community, Work and Family, 3(2), 163-184: Retrieved on 15 March 2015 from http://www.andreadoucet.com/wpcontent/uploads / 2010/11/Doucet-2000-Theres-a-HugeGulf.pdf. http://dx.doi.org/10.1080/713658907

Fajana, S. (2006). Industrial Relations in Nigeria: Theory and Features, Labofin and Company: Yaba Lagos P. 10

Fapohunda, T. M. (2014). An exploration of the effects of work life balance on productivity. Journal of Human Resources Management and Labor Studies, 2(2): 71-89. Accessed on 2nd March 2015 at.

http://aripd.org/journals/jhrmls/Vol_2_No_2_June_2014/5.pd f

George, O. J. Owoyemi, O. and Onokala, U. (2012). Evolution of Employment and Industrial Relations Practice: The Nigerian Experience. International Journal of Business and Social Science 3 (12): 188

Gill, R. (2009). Breaking the silence: the hidden injuries of the neoliberal university. In Roisin Flood \& Rosalind Gill (Eds.), Secrecy and silence in the research process: Feminist reflections pp.228-244. London: Routledge 
Graham S. L. (2003). Healthy Workplaces and Productivity: A Discussion Paper Prepared for the Economic Analysis and Evaluation Division, Health Canada. Available at http://www.cprn.org/documents/20183_en.pdf (accessed on 12 November, 2014)

Hellsten, L. M., Martin, S. L., McIntyre, L. J. and Kinzel, A. L. (2011). Women on the Academic Tenure Track: An Autoethnographic Inquiry. International Journal for Cross-Disciplinary Subjects in Education, 2(1) 271- 275 retrieved on 16 March 2015 from http://infonomicssociety.org/IJCDSE/Women\%20on\%20the\% 20Academic\%20Tenure\%20Track_An\%20Autoethnographic\%20 Inquiry.pdf.

http://dx.doi.org/10.20533/ijcdse.2042.6364.2011.0039

International Labour Organization, (2009). Workplace Well-being. Available at:.

http://www.ilo.org/safework/info/WCMS_118396/lang-en/index.htm (accessed 11 November, 2014)

Kinnunen, U., Feld, T., Geurts, S., and Pulkkinen, L. (2006). Types of work-family interface: well-being correlates of negative and positive spillover between work and family. Scandinavia Journal of Psychology, 47(2):149-62. Abstract retrieved on 15 March 2015 from http://www.ncbi.nlm.nih.gov/pubmed/ 16542357 http://dx.doi.org/10.1111/j.1467-9450.2006.00502.x

Kuther, T. (2015). Gender, stress and health in academia.Grad School Articles, available at

http://gradschool.about.com/od/forwomen/a/genderstresshea 1th.htm

Marie-Amélie B., Roxane L. G. and Lieven E. (2013) Well-being at work: creating a positive work environment: Literature review. European Agency for Safety and Health at Work (EU-OSHA) Luxembourg: Publications Office of the European Union, 2013

Mugweni, R. M., Mufanechiya, T. and Dhlomo, T. (2011). Hopes and hiccups expressed: Barriers to university female lecturers' promotion.Journal of African Studies and Development, 3(5), 8795: retrieved on 15 March 2015 from http://www.academicjournals.org/article/article1380018300_ Mugweni\%20et\%20al.pdf 
Noor, N. M. (2003). Work and family-related variables, work-family conflict and women's well-being: some observations.

Community, Work \& Family, 6 (3) 297-319: Retrieved on 15 March 2015 from

http:/ / www.humiliationstudies.org/documents / NoorWorkandF amilyrelatedVariables2003.pdf

http:/ / dx.doi.org/ 10.1080/1366880032000143474

Ogbogu, O. C. (2013). Work-Family role conflict among academic women in Nigerian Public Universities. The 2013 WEI International Academic Conference Proceedings, The West East Institute, Orlando, USA 19-24 retrieved on 16 March 2015 from http: / /www.westeastinstitute.com/wpcontent/uploads / 2013/04/ORL13-158-Christiana-Ogbogu.pdf

Ryff, C. D. (1989). Happiness is everything, or is it? Exploration of the meaning of psychological well-being. Journal of Personality and Social Psychology, 57, 1069-1081.

http:/ /dx.doi.org/ 10.1037/0022-3514.57.6.1069

Ryff, C. D. \& Keyes, C. L. M. (1995). The structure of psychological well-being revisited. Journal of Personality and Social Psychology, 69, 719-727.

http:/ /dx.doi.org/10.1037/0022-3514.69.4.719

Salami, S. O. (2009). Job -related stress, personality, social support and burnout among College of Education lecturers. African Higher Education Review 2, 39-69 Retrieved on 16 March 2015 from.http:/ / www.coe.unt.edu / sites / default/files / 1229/AHER_ Vol2.pdf

Schmidt, M. and Umans, T. (2014). Experiences of well-being among female doctoral students in Sweden. International Journal of Qualitative Studies on Health and Well-Being, 9 (10): retrieved on 15-03-2015 from

http: / / www.ncbi.nlm.nih.gov/pmc/articles/PMC3991832/

http:/ / dx.doi.org/ 10.3402/qhw.v9.23059

Shujat, S., Cheema, F. and Bhutto, F. (2011) Impact of Work Life Balance on Employee Job Satisfaction in Private Banking Sector of Karachi. Journal of Management and Social Sciences 7 (2): 08-15. Accessed on 2 March 2015 at http:/ / biztek.edu.pk/ibt/qec/7.2/2\%20Impact\%20of\%20work $\% 201$ ife.pdf 
Singh, S. (2014). Occupational well-being and burnout in personal support workers working long term care facilities Unpublished Master's Thesis of Dalhousie University Halifax, Nova Scotia. Accessed on 10 March 2015 at http://dalspace.library.dal.ca/bitstream/handle/10222/55979 / SINGH-SANGITA-MSc-OCCU-November-2014.pdf?sequence=1

SitiAisyah B. P., Azizah, R., Roziana, S., Ishak, M. S., Hamidah A., and SitiKhadijah, B. Z. (2012). Impact of Work-related Stress on Well-being among Academician in Malaysian Research University. IPEDR vol.30 available at http://www.ipedr.com/vol30/8-ICEMI\%202012-M00012.pdf (accessed 12 November, 2014)

Tehrani, N., Humpage, S., Willmott B. and Haslam, I., (2007). What's Happening with Well-being at Work? Change Agenda, Chartered Institute of Personnel and Development, London. Available at http://www.cipd.co.uk/NR/rdonlyres/DCCE94D7781A-485A-A702-6DAAB5EA7B27/0/whthapwbwrk.pdf (accessed 12 November, 2014)

Warr, P. B. (1994). A conceptual framework for the study of work and mental health. Work and Stress, 8, 84-97 http://dx.doi.org/10.1080/02678379408259982

Windebank, J. (2001). Dual-earner couples in Britain and France: gender divisions of domestic labour and parenting work in different welfare states. Work Employment and Society, 15(2), 269-290: Retrieved on 15 March 2015 from http://wes.sagepub.com/content/15/2/269.full.pdf+html http://dx.doi.org/10.1177/09500170122118959

Wood, F. (2010). How can job design workers' wellbeing and workplace performance? A presentation at Goldsmiths University of London. Available at http://www.employmentstudies.co.uk/policy/resources/101008_40bond.pdf

Received: 07-12-2015 Revised: 04-01-2016 Accepted: 12-02-2016 